\title{
COMPARATIVE STUDY OF PREGNANCY AND ITS OUTCOME BETWEEN HIV POSITIVE AND HIV NEGATIVE PREGNANT WOMAN
}

\author{
Radhika Pooli' ${ }^{1}$ J. Devi², S. Rani ${ }^{3}$
}

${ }_{1}^{1}$ Assistant Professor, Department of Obstetrics \& Gynaecology, Gandhi Medical College/Hospital, Secunderabad, Telangana. 2Senior Resident, Department of Obstetrics \& Gynaecology, Gandhi Medical College/Hospital, Secunderabad, Telangana. ${ }^{3}$ Professor, Department of Obstetrics \& Gynaecology, Gandhi Medical College/Hospital, Secunderabad, Telangana.

\section{ABSTRACT}

\section{BACKGROUND}

Maternal human immunodeficiency virus infection has impact on pregnant mother and birth outcome. The morbidity and mortality can be reduced by early identification, estimation of CD4 load and treatment of all pregnant women with HIV infection with emphasis on measures to reduce mother to child transmission. The present study compares 100 HIV seropositive women with a similar number of seronegative women with respect to maternal and fetal complications and survival.

\section{MATERIALS AND METHODS}

This study was an observational study conducted in Gandhi Hospital, Secunderabad, Telangana, India over a period of two years (2012-2014); 100 cases of HIV positive pregnant women who attended regular antenatal check-ups or admitted through labour ward in Gandhi Hospital were included in the study. CD4 count was done in HIV positive women and repeated as per the guidelines of National AIDS Control Organization (NACO). Accordingly, Antiretroviral Therapy (ART) or Antiretroviral Prophylaxis (ARV Prophylaxis) was initiated; 100 cases of HIV seronegative pregnant women were selected as controls and their maternal and fetal complications and survival were compared with that of HIV positive pregnancies.

\section{OBSERVATIONS AND RESULTS}

Caesarean section was the mode of delivery in $42 \%$ of the cases in HIV positive when compared to $37 \%$ of the cases who were HIV negative. Antepartum complications like spontaneous abortions, preterm labour were similar in both study groups. CD4 count was greater than 350 cells/cu.mm in $78 \%$ of the cases. Incidence of low birth weight, Apgar $<7$ at 5 minutes of birth and NICU admissions were significantly more in HIV positive group when compared to control group.

\section{CONCLUSION}

The study revealed that majority of HIV seropositive women were unbooked and mostly primigravida; $78 \%$ HIV positive pregnant women had CD4 count $>350$ cells/cu.mm. Delivery through caesarean section was slightly higher in HIV seropositive women. There were no statistically significant antepartum and postpartum complications in the HIV seropositive group when compared to the control group. The occurrence of low birth weight, Apgar $<7$ at 5 minutes of birth and NICU admissions were more in HIV seropositive group than in control group and this was statistically significant.

\section{KEYWORDS}

HIV in pregnancy, ART, ARV prophylaxis, MTCT, PTCT.

HOW TO CITE THIS ARTICLE: Pooli R, Devi J, Rani S. Comparative study of pregnancy and its outcome between HIV positive and HIV negative pregnant woman. J. Evolution Med. Dent. Sci. 2016;5(15):717-721, DOI: 10.14260/jemds/2016/165

\section{INTRODUCTION}

HIV is an epidemic affecting 34 million people globally with India having the third largest number of people living with HIV.[1] According to the annual report 2011-2012 NACO India, 23.9 lakh people are currently living with HIV in India with adult prevalence of $0.31 \%$, of which $39 \%$ are women.[1] The total number of annual pregnancies in India is 27 million, of which estimated number of HIV positive pregnancies is forty three thousand.

This accounts for $0.16 \%$ of annual pregnancies in India. ${ }^{[2]}$ HIV is a known contributor to poor maternal.[3] and foetal.[4] outcome. The association between HIV and adverse pregnancy outcome is a contentious issue, as it would have overarching implications for millions of HIV positive women.

Financial or Other, Competing Interest: None.

Submission 08-01-2016, Peer Review 30-02-2016,

Acceptance 10-02-2016, Published 22-02-2016.

Corresponding Author:

Dr. Radhika Pooli,

4-7-12/53, Ravindra Nagar Colony, Nacharam,

Hyderabad-500076.

E-mail: radhikapooli@yahoo.co.in

DOI: $10.14260 /$ jemds/2016/165
Universal counselling and voluntary testing is recommended for all pregnant women early in pregnancy.[5] because the appropriate antenatal interventions can reduce mother to child transmission of HIV infection and also complications of pregnancy. Infection with HIV results in spectrum of diseases, many of them poorly understood. HIV is known for its genomic variability with different types, subtypes, recombinant forms with different strains associated with different levels of virulence, different rates of MTCT and different levels of resistance to ART.

Severity of the maternal illness at the beginning of pregnancy appears to be the primary determinant of maternal and foetal outcome. In early stages of the disease, pregnant women are virtually unaffected and the perinatal outcomes are comparable with the general population. [6]

One method of assessing the stage of the disease is by testing for CD4 count, which helps in deciding for initiation of ART/ARV prophylaxis during pregnancy. Maternal antiretroviral therapy is thought to reduce transmission partly through the reduction of viral load. 
With the advent of use of ART in pregnancy, PTCT has decreased from $30-40 \%$ to $1-2 \%$ along with decrease in pregnancy complications.[7] HIV in pregnancy is associated with adverse pregnancy outcomes. ${ }^{[8]}$ including both early and late pregnancy complications like higher rates of spontaneous abortions.[9] low birth weight.[10] preterm labour.[11] premature rupture of membranes and increased risk of infection in postpartum period.[12]

The present study compares 100 HIV seropositive women with a similar number of seronegative women with respect to maternal and fetal complications and survival.

\section{MATERIALS AND METHODS}

This study was an observational study conducted in Gandhi Hospital, Secunderabad, Telangana, India over a period of two years (2012-2014). As per the hospital statistics, an average of 8500 deliveries are conducted in one year. On random basis, a total of 200 cases were included in this study. Of these, 50 percent were HIV positive pregnant women $(n=100)$ who attended regular antenatal check-ups or admitted through labour ward in Gandhi Hospital were enrolled in the study and 50 percent were HIV negative pregnant women $(n=100)$ were selected as controls in the present study. Departmental Ethical Committee clearance was obtained for the study.

HIV testing was done with ELISA technique after taking written consent of the pregnant woman at the first antenatal visit. Once the woman was diagnosed as HIV positive, CD4 count was done. This was repeated every 6 months as per the guidelines of National AIDS Control Organization (NACO).

Accordingly, HIV positive pregnant women were initiated on Antiretroviral Therapy (ART) or Antiretroviral (ARV) Prophylaxis. Transmission from mother to child is more likely with decreased maternal immune status, reflected by low CD 4 count which in turn maybe a marker for a high viral load.

As per the guidelines of NACO, ART is initiated if the CD4 count is $<350$ cells $/ \mathrm{mm} 3$, which includes lifelong use of ARV drugs to treat HIV infected pregnant women for her own health and also for prevention of Parent To Child Transmission (PTCT). The women were started on short-term ARV prophylaxis if the CD4 count was $>350$ cells $/ \mathrm{mm} 3$ to decrease the PTCT. All the other routine pregnancy investigations were done and specific investigations like sputum for culture and vaginal swab for culture and sensitivity were performed as and when required. Among the 100 cases of HIV seronegative pregnant women selected as controls, the pregnancy outcome was compared with that of HIV positive pregnancies.

The maternal complications which were compared were abortions, premature rupture of membranes, preterm labour, postpartum haemorrhage, wound healing, puerperal sepsis and maternal death. The fetal complications which were compared were intrauterine death, IUGR, low birth weight, Apgar score at 5 mins of birth, NICU admissions and neonatal deaths.

\section{STATISTICAL ANALYSIS}

Statistical analysis was done using R Programming language (Version 3.0.1). Frequencies and cross tabs were tabulated for categorical variables. Chi square test was used to see significant differences in proportions in cases and controls. P value less than 0.05 was considered significant.

\section{OBSERVATIONS AND RESULTS}

\begin{tabular}{|c|c|c|c|}
\hline & $\begin{array}{c}\text { HIV } \\
\text { POSITIVE } \\
\text { N (\%) }\end{array}$ & $\begin{array}{c}\text { HIV } \\
\text { NEGATIVE } \\
\text { N (\%) }\end{array}$ & $\begin{array}{c}P \\
\text { value }\end{array}$ \\
\hline \multicolumn{4}{|l|}{ Registration } \\
\hline $\begin{array}{l}\text { Unbooked } \\
\text { cases }\end{array}$ & $55(55 \%)$ & $43(43 \%)$ & 0.120 \\
\hline Booked cases & 45 (45\%) & 57 (57\%) & \\
\hline \multicolumn{4}{|l|}{ Parity } \\
\hline Primigravida & $58(58 \%)$ & $44(44 \%)$ & 0.066 \\
\hline Multigravida & $42(42 \%)$ & $56(56 \%)$ & \\
\hline \multicolumn{4}{|l|}{$\begin{array}{l}\text { Type of } \\
\text { delivery }\end{array}$} \\
\hline $\begin{array}{l}\text { Vaginal } \\
\text { delivery }\end{array}$ & $58(58 \%)$ & $63(63 \%)$ & 0.563 \\
\hline C-Section & $42(42 \%)$ & 37 (37\%) & \\
\hline \multicolumn{4}{|l|}{$\begin{array}{l}\text { Spontaneous } \\
\text { abortions }\end{array}$} \\
\hline Yes & $3(3 \%)$ & $5(5 \%)$ & 0.718 \\
\hline No & $97(97 \%)$ & 95 (95\%) & \\
\hline \multicolumn{4}{|l|}{$\begin{array}{l}\text { Preterm } \\
\text { labour }\end{array}$} \\
\hline Yes & $9(9 \%)$ & $8(8 \%)$ & 0.999 \\
\hline No & $91(91 \%)$ & $92(92 \%)$ & \\
\hline \multicolumn{4}{|l|}{ PROM } \\
\hline Yes & $15(15 \%)$ & $12(12 \%)$ & 0.679 \\
\hline No & $85(85 \%)$ & $88(88 \%)$ & \\
\hline \multicolumn{4}{|l|}{ UTI } \\
\hline Yes & $6(6 \%)$ & $4(4 \%)$ & 0.746 \\
\hline No & $94(94 \%)$ & $96(96 \%)$ & \\
\hline \multicolumn{4}{|c|}{$\begin{array}{c}\text { Table 1: Antenatal Profile of HIV Positive and } \\
\text { Negative Pregnant Women }\end{array}$} \\
\hline
\end{tabular}

The number of unbooked cases accounted for $55 \%$ of the cases in the HIV positive group and $43 \%$ of the cases in the HIV negative group, whereas in booked cases it accounted for $45 \%$ in HIV positive group and $57 \%$ in HIV negative group. The numbers of primi gravida were more (P value trend) in the HIV positive group and multigravidas were more in HIV negative group. Caesarean section was the mode of delivery in $42 \%$ of the cases in HIV positive when compared to $37 \%$ of the cases in HIV negative group. The occurrence of antepartum complications like spontaneous abortions, preterm labour were similar in both study groups. As the $\mathrm{p}$ values are $>0.05$ antepartum complications in the HIV seropositive women are not significant in this study. 


\begin{tabular}{|c|c|}
\hline HIV Pregnant women & N (\%) \\
\hline Time of diagnosis & $90(90 \%)$ \\
\hline Diagnosed during pregnancy & $10(10 \%)$ \\
\hline Diagnosed prior to pregnancy & \\
\hline $\begin{array}{c}\text { Gestational age according to } \\
\text { trimester }\end{array}$ & $5(5 \%)$ \\
\hline $1^{\text {st }}$ Trimester & $70(70 \%)$ \\
\hline $2^{\text {nd }}$ Trimester & $25(25 \%)$ \\
\hline $3^{\text {rd }}$ Trimester & $10(10 \%)$ \\
\hline CD4 Count & $78(78 \%)$ \\
\hline$<350$ cells/cu.mm & $12(12 \%)$ \\
\hline$>350$ cells/cu.mm & $5(5 \%)$ \\
\hline Not known & $70(70 \%)$ \\
\hline Gestational Age & $25(25 \%)$ \\
\hline 1 ${ }^{\text {st }}$ Trimester & Trimester \\
\hline 3rd Trimester & Table 2: Profile of HIV pregnant \\
\hline \multicolumn{2}{|c|}{ women during the study } \\
\hline \multicolumn{2}{|c|}{} \\
\hline \multicolumn{2}{|c|}{} \\
\hline
\end{tabular}

The majority of HIV seropositive pregnant women in the study were diagnosed to be HIV positive during pregnancy. At the time of diagnosis, $70 \%$ of the cases were diagnosed during second trimester, 25\% during third trimester and 5\% during the first trimester. CD4 count was greater than 350 cells/cu.mm in $78 \%$ of the cases, lesser than 350 cells/cu.mm in $40 \%$ of the cases and in $12 \%$ of the cases count was unknown. In $70 \%$ of cases HIV infected women were started on ARV during second trimester, in $25 \%$ of cases during third trimester and in 5\% cases during first trimester.

\begin{tabular}{|c|c|c|c|}
\hline & $\begin{array}{c}\text { HIV } \\
\text { POSITIVE } \\
\text { N (\%) }\end{array}$ & $\begin{array}{c}\text { HIV } \\
\text { NEGATIVE } \\
\text { N (\%) }\end{array}$ & $P$ value \\
\hline \multicolumn{4}{|l|}{$\begin{array}{c}\text { Postpartum } \\
\text { haemorrhage }\end{array}$} \\
\hline Yes & $1(1 \%)$ & $1(1 \%)$ & 0.999 \\
\hline No & 99 (99\%) & 99 (99\%) & \\
\hline \multicolumn{4}{|l|}{$\begin{array}{l}\text { Puerperal } \\
\text { sepsis }\end{array}$} \\
\hline Yes & $0(0 \%)$ & $2(2 \%)$ & 0.477 \\
\hline No & $\begin{array}{c}100 \\
(100 \%)\end{array}$ & 98 (98\%) & \\
\hline \multicolumn{4}{|l|}{$\begin{array}{c}\text { Wound } \\
\text { infections }\end{array}$} \\
\hline Yes & $2(2 \%)$ & $6(6 \%)$ & 0.279 \\
\hline No & $98(98 \%)$ & $94(94 \%)$ & \\
\hline \multicolumn{4}{|l|}{ Skin infection } \\
\hline Yes & $0(0 \%)$ & $0(0 \%)$ & $\begin{array}{c}\text { Not } \\
\text { applicable }\end{array}$ \\
\hline No & $\begin{array}{c}100 \\
(100 \%)\end{array}$ & $100(100 \%)$ & \\
\hline \multicolumn{4}{|l|}{ Mortality } \\
\hline Yes & $0(0 \%)$ & $0(0 \%)$ & $\begin{array}{c}\text { Not } \\
\text { applicable }\end{array}$ \\
\hline No & $\begin{array}{c}100 \\
(100 \%)\end{array}$ & $100(100 \%)$ & \\
\hline \multicolumn{4}{|c|}{$\begin{array}{l}\text { Table 3: Post-partum profile of HIV } \\
\text { positive and negative pregnant women }\end{array}$} \\
\hline
\end{tabular}

Occurrence of postpartum complications like PPH, puerperal sepsis and wound infections was not statistically significant. There was no maternal mortality in both the groups.

\begin{tabular}{|c|c|c|c|}
\hline & $\begin{array}{c}\text { HIV } \\
\text { POSITIVE } \\
\text { N (\%) }\end{array}$ & $\begin{array}{c}\text { HIV } \\
\text { NEGATIVE } \\
\text { N (\%) }\end{array}$ & $\begin{array}{c}P \\
\text { value }\end{array}$ \\
\hline \multicolumn{4}{|l|}{ Live births } \\
\hline Yes & 97 (97\%) & 97 (97\%) & 0.999 \\
\hline No & $3(3 \%)$ & $3(3 \%)$ & \\
\hline \multicolumn{4}{|l|}{ LBW } \\
\hline Yes & $36(36 \%)$ & $18(18 \%)$ & 0.007 \\
\hline No & $64(64 \%)$ & $82(82 \%)$ & \\
\hline \multicolumn{4}{|l|}{$\begin{array}{l}\text { Apgar }<7 \text { at } 5 \\
\text { min of birth }\end{array}$} \\
\hline Yes & $20(20 \%)$ & $5(5 \%)$ & 0.003 \\
\hline No & $80(80 \%)$ & $95(95 \%)$ & \\
\hline \multicolumn{4}{|l|}{ Still births } \\
\hline Yes & $1(1 \%)$ & $1(1 \%)$ & 0.999 \\
\hline No & $99(99 \%)$ & $99(99 \%)$ & \\
\hline \multicolumn{4}{|l|}{$\begin{array}{c}\text { NICU } \\
\text { admissions }\end{array}$} \\
\hline Yes & $20(20 \%)$ & $6(6 \%)$ & 0.006 \\
\hline No & $80(80 \%)$ & $94(94 \%)$ & \\
\hline \multicolumn{4}{|l|}{ Discharged } \\
\hline Yes & $17(17 \%)$ & $5(5 \%)$ & 0.013 \\
\hline No & $83(83 \%)$ & 95 (95\%) & \\
\hline \multicolumn{4}{|l|}{ Death } \\
\hline Yes & $3(3 \%)$ & $1(1 \%)$ & 0.614 \\
\hline No & $97(97 \%)$ & $99(99 \%)$ & \\
\hline \multicolumn{4}{|l|}{ IUGR } \\
\hline Yes & $1(1 \%)$ & $7(7 \%)$ & 0.071 \\
\hline No & $99(99 \%)$ & $93(93 \%)$ & \\
\hline \multicolumn{4}{|l|}{ IUD } \\
\hline Yes & $2(2 \%)$ & $2(2 \%)$ & 0.999 \\
\hline No & $98(98 \%)$ & $98(98 \%)$ & \\
\hline \multicolumn{4}{|c|}{$\begin{array}{l}\text { Table 4: Foetal and Neonatal profile of HIV } \\
\text { positive and negative pregnant women }\end{array}$} \\
\hline
\end{tabular}

Among the study groups, occurrence of low birth weight, Apgar $<7$ at 5 minutes of birth and NICU admissions were significantly more in HIV positive group when compared to control group.

\section{DISCUSSION}

In the present study the number of unbooked cases (55\%) were more than the number of booked cases in the HIV seropositive group. In the seronegative group the booked cases constituted the major group, i.e. $57 \%$. As this hospital is a tertiary care centre, the cases were referred from PHCs and this resulted in more number of unbooked cases. Primigravidae formed the majority of the HIV positive pregnant women (58\%), multiparty being common among seronegative women (44\%). This may be due to increased awareness regarding the risk of transmission during the pregnancy and limitation of child bearing in HIV seropositive women.

$90 \%$ of the HIV positive pregnant women were diagnosed during pregnancy. This is because of universal counselling and voluntary testing during the antenatal period. Majority of the women were diagnosed as HIV positive during the second trimester (70\%). This is because most of the women belonged to the low socioeconomic status with no antenatal visits in the first trimester. In $90 \%$ of HIV positive pregnant women, route of transmission was sexual. 
$78 \%$ of the HIV positive pregnant women had CD4 count of $>350$ cells thus needing only short-term ARV prophylaxis. Advantages of ARV being reduction of maternal viral replication and viral load, treatment of maternal infection, preexposure prophylaxis in baby and improvement of overall maternal health. ARVs are safe, well tolerated and easy to use in pregnant women who are carefully monitored.

In this study, the rate of caesarean section was $42 \%$ in HIV positive women and $37 \%$ in the control group. This is important because Caesarean section reduces the mother to child transmission rate. In-utero transmission is less frequent and a substantial proportion of infection occurs at the time of delivery.

Spontaneous abortions were 3\% in HIV positive group and $5 \%$ in control group. This is comparable to study conducted by Archana Tripathi et al. 2013.[13] As p value is 0.5, it is not significant in the present study. Occurrence of preterm labour was similar in both the study groups, $9 \%$ in HIV positive and $8 \%$ in control group. The results were similar to a study conducted by B. Vandercam et al.[14] in 2003 with p value being 0.8 , it is not statistically significant in our study. In this study, PROM complicating pregnancy in HIV positive women accounted for $15 \%$. The p value is 0.5 , which is statistically not significant.

The present study showed no increase in postpartum complications like postpartum haemorrhage, puerperal sepsis, wound infection in the HIV seropositive women as compared to the control group. There was no statistically significant difference in stillbirth in the study group and control group. The number of intrauterine deaths were same in both the groups. In this study, the number of live births were similar in both the groups, i.e. $97 \%$. IUGR was seen in $1 \%$ of cases in HIV seropositive women and $7 \%$ in control group in the present study, while the study conducted by Joseph 0 , et al. 2011.[15] showed IUGR in $20 \%$ of study group and the study conducted by Archana Tripathi et al. 2013 had IUGR in 6\% of seropositive women and $14 \%$ in seronegative women. In our study, low birth weight was seen in $36 \%$ of HIV positive women and $18 \%$ in control group which is comparable to study conducted by Joseph 0 , et al. 2011.[15] This observation is statistically significant with p value being 0.004 .

Apgar score less than 7 at 5 minutes of birth was seen in $20 \%$ of the study group and $5 \%$ in control group in our study. This is statistically significant with a $\mathrm{p}$ value of 0.001 . Two main causes of low Apgar at birth were due to foetal distress and respiratory distress due to unidentified reasons. Low Apgar and low birth weight were responsible for NICU admissions in $20 \%$ of neonates of HIV positive mothers as compared to $6 \%$ of neonates of mothers in the control group, this being statistically significant with $p$ value 0.003 .

Of the $20 \%$ NICU admissions in the study, $17 \%$ were discharged and there were $3 \%$ deaths in neonates of HIV positive women, while in the control group of $6 \%$ NICU admissions $5 \%$ were discharged and there was $1 \%$ neonatal deaths, this having no statistical significance with $\mathrm{p}$ value of 0.37 .

\section{CONCLUSION}

The study has revealed that majority of HIV seropositive women were unbooked cases. Majority of the women in HIV seropositive group were primigravida.

CD4 count more than 350 cells/cu.mm was found in $78 \%$ HIV positive pregnant women.
Delivery through caesarean section was slightly higher in HIV seropositive women than in control group, as it is one of the interventions to decrease the risk of vertical transmission.

There were no statistically significant antepartum and postpartum complications in the HIV seropositive group when compared to the control group.

The occurrence of low birth weight, Apgar $<7$ at 5 minutes of birth and NICU admissions were more in HIV seropositive group than in HIV negative control group, which was statistically significant. However, to establish this association further studies are required taking into consideration other confounding factors like maternal social factors, nutritional factors and associated pregnancy complications.

\section{ABBREVIATIONS}

HIV: Human Immunodeficiency Virus. MTCT: Mother to Child Transmission. PTCT: Parent to Child Transmission. ART: Anti-Retroviral Therapy. ARV Prophylaxis: Anti-Retroviral Prophylaxis. NACO: National AIDS Control Organization.

\section{REFERENCES}

1. Annual report 2011-2012 National AIDS Control Organization India, Department of AIDS Control, Ministry of Health and Family Welfare (2012).

2. Annual report 2009-2010, AIDS Control Organization India, Department of AIDS Control, Ministry of Health and Family Welfare (2010).

3. Wandabwa JN, et al. HIV and AIDS and other important predictors of maternal mortality in Mulago Hospital Complex, Kampala, Uganda. BMC Public Health 2011;11:565.

4. Brahmbhatt $\mathrm{H}$, et al. Mortality in HIV infected and uninfected children of HIV infected and uninfected mothers in rural Uganda. J Acquired Immune Deficiency syndrome 2006;41(4):504-8.

5. American College of Obstetricians and Gynaecologists: Prenatal and perinatal human immunodeficiency virus testing: expanded recommendations. Committee opinion No. 304, Nov 2004.

6. Bodkin C, et al. A comparison of HIV positive and HIV negative pregnant women at a public sector hospital in South Africa. J Clin Nurse 2006;15:735-41.

7. NACO Annual Report 2010-11, National AIDS Control Organization India, Department of AIDS Control, Ministry of Health and Family Welfare (2011).

8. Timmerman M, et al. Infection with HIV as risk factor for adverse pregnancy outcome. AIDS 1990;4:139-144.

9. Shearer WT, Langston C, et al. Early spontaneous abortions and fetal thymic abnormalities in maternal-to-fetal infection. Acta Paediatr 1997; Suppl 421:60-64.

10. Taha TET, et al. The effect of human immunodeficiency virus infection on birth weight and infant and child survival in urban Malawi. Int J Epidemiol 1995;24:10221028.

11. Patel MA, et al. Pregnancy outcome in HIV seropositive women. J Obstet Gynaecol India 2000;50(4):48.

12. Bulterys M, et al. Fatal complications after caesarean section in HIV-infected women. AIDS 1996;10(8):923-924. 
13. Archana Tripathi. To study the prevalence of HIV infection in pregnant women and its effect on perinatal outcome. Journal of Evolution of Medical and Dental Sciences 2013;42:8002-8005.

14. Vandercam B, et al. Highly active antiretroviral therapy (HAART) in pregnant HIV-infected women. Efficacy and safety for the mothers and infants. The XV International AIDS Conference: Abstract no. B12036.
15. Joseph O, et al. Pregnancy outcome among HIV positive women receiving antenatal HAART versus untreated maternal HIV infection. J Coll Physicians Surg Pak 2011 Jun;21(6):356-9. 